\title{
The challenge of obtaining information necessary for multi-criteria decision analysis implementation: the case of physiotherapy services in Canada
}

Francois Dionne ${ }^{1 *}$, Craig Mitton ${ }^{1}$, Tanya MacDonald ${ }^{2}$, Carol Miller ${ }^{2}$ and Michael Brennan²

\begin{abstract}
Background: As fiscal constraints dominate health policy discussions across Canada and globally, priority-setting exercises are becoming more common to guide the difficult choices that must be made. In this context, it becomes highly desirable to have accurate estimates of the value of specific health care interventions. Economic evaluation is a well-accepted method to estimate the value of health care interventions. However, economic evaluation has significant limitations, which have lead to an increase in the use of Multi-Criteria Decision Analysis (MCDA). One key concern with MCDA is the availability of the information necessary for implementation. In the Fall 2011, the Canadian Physiotherapy Association embarked on a project aimed at providing a valuation of physiotherapy services that is both evidence-based and relevant to resource allocation decisions. The framework selected for this project was MCDA. We report on how we addressed the challenge of obtaining some of the information necessary for MCDA implementation.
\end{abstract}

Methods: MCDA criteria were selected and areas of physiotherapy practices were identified. The building up of the necessary information base was a three step process. First, there was a literature review for each practice area, on each criterion. The next step was to conduct interviews with experts in each of the practice areas to critique the results of the literature review and to fill in gaps where there was no or insufficient literature. Finally, the results of the individual interviews were validated by a national committee to ensure consistency across all practice areas and that a national level perspective is applied.

Results: Despite a lack of research evidence on many of the considerations relevant to the estimation of the value of physiotherapy services (the criteria), sufficient information was obtained to facilitate MCDA implementation at the local level.

Conclusions: The results of this research project serve two purposes: 1) a method to obtain information necessary to implement MCDA is described, and 2) the results in terms of information on the benefits provided by each of the twelve areas of physiotherapy practice can be used by decision-makers as a starting point in the implementation of MCDA at the local level.

Keywords: Physiotherapy, MCDA, Resource Allocation, Priority Setting

\footnotetext{
* Correspondence: fdionne@telus.net

${ }^{1}$ Centre for Clinical Epidemiology and Evaluation, Vancouver Coastal Health

Research Institute, School of Population and Public Health, University of

British Columbia, 7th Floor, 828 West 10th Avenue, Research Pavilion,

Vancouver, BC V5Z 1M9, Canada

Full list of author information is available at the end of the article
} 


\section{Background}

As fiscal constraints dominate health policy and planning discussions both across Canada and globally, prioritysetting exercises are becoming more common to guide the difficult choices that must be made [1]. In this context, it is not only appropriate but also highly desirable to assess the value of specific health care services, as an assessment of value is necessary for priority setting on resource allocation either through the use of a threshold (minimum value per dollar spent) or through a formalized priority-setting process such as Program Budgeting and Marginal Analysis (PBMA).

A common approach to the assessment of the value of health care services is economic evaluation [2]. Economic evaluation is typically used in a threshold approach to resource allocation, meaning that interventions costing less than a threshold cost per unit of benefit are deemed worthy of funding. However, there are well-known challenges to the acceptability of economic evaluation as a tool to guide resource allocation decisions. A key such challenge is to "ensure alignment between the objectives assumed in economic analyses and the objectives facing decision-makers in reality" [3]. Specifically, economic evaluation as a priority setting tool assumes that the decision-maker's objective is to maximize health gain [4] but we know that other objectives are also typically pursued $[4,5]$. One solution offered is that "the simple C/E ratio could be supplemented by information on other health effects for the patient, for example a descriptive account of expected improvements in quality of life; wider societal effects of the intervention, for example on the number of jobs created; and nonmonetary costs for the patient reported in natural units such as waiting time in days" [4]. Such a solution can in fact be formalized through the use of Multi-Criteria Decision Analysis (MCDA): "MCDA is aimed at supporting decision makers faced with evaluating alternatives, taking into account multiple, and often conflictive (sic), criteria" [6]. The criteria in MCDA are the 'other health effects', the 'wider societal effects' and the 'nonmonetary costs' referred to above, or put simply, the considerations that a decision-maker will typically take into account in making a decision on resource allocation. MCDA is typically used in formal priority setting processes such as Program Budgeting and Marginal Analysis (PBMA). Like economic evaluation, MCDA has methodological challenges, but in many contexts, because it formally includes most or all considerations relevant to decision-making, this approach, and the associated priority setting frameworks, fit the decision-maker's perspective better $[7,8]$. One key methodological challenge of MCDA is the search for the necessary information. The necessary information is often not readily available for two main reasons. First, some of the criteria, while relevant to decisionmakers, are typically not common research subjects. This would include criteria such as integration or access. Second, even when literature is available, the information must be contextualized before it can be used. This paper reports on an example of how this key challenge can be addressed.

In the Fall 2011, the Canadian Physiotherapy Association (CPA) embarked on a project aimed at providing a valuation of physiotherapy services that is both evidencebased and relevant to resource allocation decisions in health care organizations. This project originated more than one year earlier, in 2010, when the CPA Branch Presidents concluded that there was a need for more information on the value of physiotherapy services and asked the CPA national staff to consider developing a document that would address this need. After investigating the methodological alternatives, the CPA national staff decided to proceed with the MCDA framework.

In this paper we report on the methods used to obtain information necessary for MCDA implementation and provide a brief summary of the information that was produced. The objective is to show how a key challenge to the implementation of MCDA can be addressed and give a sample of the results. The full results which are in the final report are the starting point for an MCDA implementation. Actual examples of full implementation of MCDA within a priority setting process at the local level, building on the information produced in this project, are not included.

\section{Methods}

MCDA involves the assessment of alternative actions on the basis of a common set of criteria $[9,10]$. The two key elements of the MCDA process are the alternatives to be considered and the criteria to be used. Possible alternatives are those options available to the decision-maker, for example changing the level of funding for a given physiotherapy service or program. The criteria represent the relevant considerations in assessing the impact of implementing any of the different alternatives. Criteria therefore depend on the decision-making context. Once possible alternatives have been evaluated on the basis of the selected criteria, they can be compared and recommendations can be formulated. The evaluation of each alternative provides an assessment of what would be lost, in cases of a reduction in funding, and what would be gained, in case on increases in funding. When contextualized, this valuation represents the marginal value of a service at the local level (as opposed to the total or average value) as the question that was posed with respect to each criterion was: what would be the impact on this criterion of an increase or a decrease to the current volume of service. The basic steps in MCDA are outlined in Table 1. 


\section{Table 1 MCDA steps}

1 The first step is the development of relevant criteria. The criteria should be clearly defined and must relate to the overall purpose of the decision process. The objective in the development of criteria is to include all considerations relevant to the decision that has to be made and to provide sufficient clarity to ensure consistency in the translation of information about the alternatives into ratings.

2 The second step is the identification of the possible alternatives. In this case, the alternatives are the most common physiotherapy services. Each alternative [or in this case set of services] must be accompanied by the information required to assess it on the basis of the established criteria.

3 The third step is the formal evaluation of each possible alternative. This is done by rating each alternative on each criterion and calculating a composite score. Because the same criteria are used with all alternatives, the scores are comparable across all alternatives.

4 The final step is the formulation of recommendations. First, each composite score is validated to ensure that no process errors took place. Once that is done, each alternative can be ranked in relation to all others. Funding recommendations are then based on this ranking.

The first step in the application of MCDA to the valuation of physiotherapy services was to determine a set of criteria relevant to decision making on health care resource allocation involving such services. The perspective adopted for this project was that of a decision maker within a health region or health service delivery organization, as this was the primary target audience for this work. Based on previous priority setting work with Canadian health authorities and on the literature on priority setting [11-14] an initial set of criteria was proposed to the CPA and, through discussion, a final list of eleven criteria was developed (see Table 2). The criteria were defined in such a way as to ensure that overlap was minimized [i.e., they are meant to be mutually exclusive, as much as possible].

Moving to step two, the CPA identified a set of service areas for assessment, based on relevant literature and similar briefings on value for money developed in the United Kingdom by the Chartered Society of Physiotherapy. The final list contained twelve service areas (see Table 3).

This research project was about the second part of step two which is to obtain information necessary to assess each alternative on the basis of each criterion. This

\section{Table 2 Criteria and definitions}

\begin{tabular}{|c|c|}
\hline Resource impact & Impact on system-wide resource use \\
\hline Quality of Life & $\begin{array}{l}\text { This criterion deals with the absolute change in quality of life, i.e. a service that has a limited impact on } \\
\text { quality of life could not rate to the top of the scale on this criterion. }\end{array}$ \\
\hline
\end{tabular}

Integration

Access

Equity

Effectiveness

Appropriateness

Acceptability

Implementation challenges

Impact on future use of health care services [3+years]
This criterion is about the continuum of care [and goes beyond the health care system]. Does the service address a gap in the continuum of care that facilitates the clients' transition from one program or service to another?

This criterion measures the impact of the provision of a given service on the current utilization of other services, thereby possibly making these other services more accessible. For example, if a given service results in fewer hours per week of home care being required, then this service has freed up those hours for someone else to use. Some services will free up resources that way and some won't.

Impact of the service on the health status of groups where there is an avoidable, unfair, and remediable health status gap.

This is about the absolute effectiveness of the service. Just because a service is the best that can be done for an underlying condition does not mean that it is highly effective. Also effectiveness is measured with respect to the impact on the underlying condition itself or the impact on the consequences of the underlying condition.

This criterion deals with the high level degree of match between a given service and the overall needs of the population, defined as the combination of the number of persons with the underlying condition and the impact of the underlying condition on quality of life. We should also consider here the availability of possible alternatives. Alternatives to be considered here can be privately provided services but also different services that are publicly funded. We are getting at the idea of the possibility of substitution with this criterion.

This deals with the relative 'displeasure' associated with the service delivery- amount of pain, discomfort

Risks associated with the implementation of given service change [for example, increased volume] but also degree of support- this would be measured, amongst other considerations, by the extent of public pressure in favour of a service.

This criterion is about the extent to which the provision of a physiotherapy service now is likely to affect the overall use of health care services down the road [at least three years from now]. 


\section{Table 3 Selected service areas for review}

\begin{tabular}{ll}
\hline 1. & Physiotherapy interventions for musculoskeletal conditions \\
2. & Physiotherapy interventions for low back pain \\
3. & Rehabilitation services in the intensive care unit \\
4. & Physiotherapy interventions for chronic disease management \\
5. & Rehabilitation services for chronic lung disease \\
6. & Rehabilitation services for cardiovascular disease \\
7. & Rehabilitation services following joint arthroplasty \\
8. & Rehabilitation services following stroke \\
9. & Physiotherapy services in the emergency department \\
10. & Home based rehabilitation services \\
11. & Rehabilitation services for falls \\
12. & Rehabilitation services for pediatrics \\
\hline
\end{tabular}

was done in a three part process. First, a literature review was undertaken to identify peer reviewed papers that address the notion of value (as defined by the criteria). Search terms included the given service area along with 'effectiveness', 'cost-effectiveness', 'value' and a myriad of other terms relating to the identified criteria. Due to the breadth of the search, a systematic review was not attempted; rather key papers were identified and reviewed with the intent of providing insight into a given service area, as opposed to a comprehensive take on each area. Not surprisingly, for many of the criteria there was no, or very limited, research evidence. The second part of the search for information or evidence was a series of interviews with content experts for each of the twelve service areas. These content experts $(n=1$ to 3 depending on the service area) were identified by the CPA. Through one or more phone consultations, the literature review for each service area was critiqued and new information was generated where no, or insufficient, literature existed. This was an important part of the process as the literature only provided information on some of the criteria. The missing, but required, pieces of information thus came from expert opinion. It is in this combining of expert opinion with research finding that MCDA provides a pragmatic approach to valuation.

After drafting of an initial synthesis document by service area which combined the results of the literature review with expert opinion, there remained a need to ensure that 1) the information presented would be applicable at a national level (as opposed to the provincial or regional level) and 2) the assessments would be consistent across the service areas (noting that the content experts were only focusing on a single service area). For this purpose, in the third part of the process to acquire the required information, the CPA struck a validation committee comprised of eleven individuals from across Canada with a broad range of experience in physiotherapy. Over the course of 2 two- hour meetings, the synthesis document was reviewed in detail. In some cases the validation committee requested additional information from the literature and clarification of points made by the content experts. The synthesis document was then adjusted to reflect the comments from the validation committee, including additional research information and clarification of expert opinions, resulting in the final synthesis by service area. Steps three and four of the MCDA process were not included in this project as those steps are context-dependant by nature.

\section{Results: Key findings by service areas}

In this section, we present the some of the key findings by service area. This section is limited to select key findings because full presentation is beyond the scope of this paper: we have 11 criteria and 12 service areas which means 132 cells of information which in the final report represented 55 pages of content. Where findings are based on published evidence, references are provided. When there is no reference, the findings are expert opinion, obtained as described above. Further details, including the key findings for each criteria, for each of the twelve service areas are presented in Table 4 (there again, where findings are from the literature, references are cited). Complete results can be found in the CPA report 'Valuing Physiotherapy Services' [15]. The findings presented here represent the minimum starting point required to implement MCDA at a local level. In the Discussion, we describe how these results can be used in an MCDA exercise in a health service organization.

\section{Pediatrics}

The cost of providing pediatric physiotherapy services tends to be higher than treatment for adults, however the long-term benefits and decreased burden on future use of care services can be significant. Besides the expected direct impact, for example, the direct impact on children with juvenile idiopathic arthritis [30], with cerebral palsy [31], or with cystic fibrosis [32], there are two important benefits of pediatric physiotherapy that emerged: 1) the physiotherapist typically develops a supportive relationship with both the child and his or her family. In this role, the therapist is an essential source of information and education making the physiotherapist a valued link to, and guide through, an often-times overwhelming care process for children and their parents; and 2) pediatric physiotherapy services play an important role in the transition to adulthood. Therapists can act as a bridge between programs to ensure the continuation of treatment while transitioning from child to adult care.

\section{Home-based services}

Home-based physiotherapy services are highly effective for many health conditions, including frailty in elderly 
Table 4 Key findings by criteria service areas

\begin{tabular}{|c|c|c|c|c|c|c|c|c|c|c|c|}
\hline & $\begin{array}{l}\text { Resource } \\
\text { impact }\end{array}$ & Quality of life & $\begin{array}{l}\text { Patient/ } \\
\text { provider } \\
\text { satisfaction }\end{array}$ & Integration & Access & Equity & Effectiveness & Appropriateness & Acceptability & $\begin{array}{l}\text { Implementation } \\
\text { challenges }\end{array}$ & $\begin{array}{l}\text { Impact on } \\
\text { future use of } \\
\text { health care } \\
\text { services }\end{array}$ \\
\hline $\begin{array}{l}\text { 1. Physiotherapy } \\
\text { interventions for } \\
\text { musculoskeletal } \\
\text { conditions }\end{array}$ & $\begin{array}{l}\text { For non-urgent } \\
\text { MSK patients, } \\
\text { physiotherapists } \\
\text { found to be } \\
\text { highly effective } \\
\text { gatekeepers to } \\
\text { surgical care, } \\
\text { providing } \\
\text { appropriate } \\
\text { assessment and } \\
\text { management of } \\
\text { patient needs; } \\
\text { reduces costs of } \\
\text { outpatient care } \\
\text { [16] }\end{array}$ & $\begin{array}{l}\text { Clear } \\
\text { relationship } \\
\text { between } \\
\text { improved } \\
\text { functioning and } \\
\text { impact on } \\
\text { quality of life }\end{array}$ & $\begin{array}{l}\text { Patient } \\
\text { satisfaction with } \\
\text { physiotherapy } \\
\text { treatment } \\
\text { correlated to } \\
\text { personal } \\
\text { responsibility for } \\
\text { managing } \\
\text { disorder; } \\
\text { recommend } \\
\text { adjusting } \\
\text { treatment to } \\
\text { match attitude or } \\
\text { attempt to } \\
\text { change attitude } \\
\text { [17]. As a } \\
\text { provider, very } \\
\text { rewarding area } \\
\text { to work; client- } \\
\text { centred } \\
\text { approach; } \\
\text { increases } \\
\text { therapist's drive } \\
\text { to improve their } \\
\text { skills }\end{array}$ & $\begin{array}{l}\text { Physiotherapy } \\
\text { can fill gaps for } \\
\text { someone who is } \\
\text { below threshold } \\
\text { of MSK health; } \\
\text { helps to raise } \\
\text { client to } \\
\text { minimum } \\
\text { threshold so they } \\
\text { can then move } \\
\text { into the } \\
\text { community and } \\
\text { access personal } \\
\text { trainers }\end{array}$ & $\begin{array}{l}\text { Limited impact } \\
\text { on concurrent } \\
\text { use of other } \\
\text { services: } \\
\text { possibly better } \\
\text { use of } \\
\text { surgeons' time }\end{array}$ & $\begin{array}{l}\text { Disparity } \\
\text { between patients } \\
\text { not privately } \\
\text { insured and } \\
\text { those insured; } \\
\text { similarly with on- } \\
\text { site access versus } \\
\text { off-site. Access } \\
\text { tied to SES; few } \\
\text { resources for } \\
\text { those with low } \\
\text { income }\end{array}$ & $\begin{array}{l}\text { Outpatient } \\
\text { multidisciplinary } \\
\text { treatment } \\
\text { program for } \\
\text { sick-listed } \\
\text { workers highly } \\
\text { effective in } \\
\text { improving } \\
\text { physical } \\
\text { functioning, } \\
\text { physical } \\
\text { disabilities, and } \\
\text { kinesiophobia } \\
\text { compared to } \\
\text { usual care; no } \\
\text { significant } \\
\text { difference in } \\
\text { cost- } \\
\text { effectiveness on } \\
\text { the societal level } \\
\text { as compared to } \\
\text { usual care }\end{array}$ & $\begin{array}{l}\text { Orthopedic } \\
\text { surgeons more } \\
\text { likely to refer } \\
\text { patients to PT } \\
\text { than primary } \\
\text { physicians; self- } \\
\text { referral patients } \\
\text { had lower PT } \\
\text { visits than } \\
\text { physician referred } \\
\text { [17]. Need to } \\
\text { increase therapy } \\
\text { resources to } \\
\text { address barriers } \\
\text { to access [18] }\end{array}$ & $\begin{array}{l}\text { Some services } \\
\text { are quite } \\
\text { uncomfortable } \\
\text { (e.g., } \\
\text { shoulders); but } \\
\text { generally, } \\
\text { clients do not } \\
\text { stop due to } \\
\text { discomfort; } \\
\text { have to put } \\
\text { treatment into } \\
\text { broader picture } \\
\text { of helping the } \\
\text { client which } \\
\text { may, at times, } \\
\text { be painful }\end{array}$ & $\begin{array}{l}\text { Public does not } \\
\text { necessarily know } \\
\text { what } \\
\text { physiotherapy is; } \\
\text { people who } \\
\text { might benefit } \\
\text { may not know } \\
\text { how to access } \\
\text { services or are } \\
\text { unaware of how } \\
\text { it would be } \\
\text { beneficial. Need } \\
\text { public and other } \\
\text { professionals to } \\
\text { be more aware of } \\
\text { skills and impact } \\
\text { of PT }\end{array}$ & $\begin{array}{l}\text { Creating } \\
\text { individualized } \\
\text { programs and } \\
\text { allowing for } \\
\text { independent } \\
\text { care outside of } \\
\text { physiotherapy } \\
\text { can result in } \\
\text { lifelong changes: } \\
8 \text { weeks post- } \\
\text { physiotherapy } \\
\text { may not result in } \\
\text { significant } \\
\text { changes; } \\
\text { however, large } \\
\text { changes at 12- } \\
\text { month; in } \\
\text { addition, if re- } \\
\text { injury occurs, } \\
\text { costs are much } \\
\text { lower }\end{array}$ \\
\hline $\begin{array}{l}\text { 2. Physiotherapy } \\
\text { interventions for } \\
\text { low back pain }\end{array}$ & $\begin{array}{l}\text { Physiotherapist- } \\
\text { led pain } \\
\text { management } \\
\text { classes offer a } \\
\text { cost-effective } \\
\text { alternative to } \\
\text { usual outpatient } \\
\text { physiotherapy } \\
\text { and are } \\
\text { associated with } \\
\text { less healthcare } \\
\text { use [19] }\end{array}$ & $\begin{array}{l}\text { Reduces pain } \\
\text { and improves } \\
\text { functioning, } \\
\text { especially for } \\
\text { chronic } \\
\text { condition } \\
\text { (confirmed } \\
\text { through the } \\
\text { administration } \\
\text { of pre and post } \\
\text { surveys) }\end{array}$ & $\begin{array}{l}\text { Hands on } \\
\text { individual care } \\
\text { that results in } \\
\text { patient } \\
\text { satisfaction; } \\
\text { individualized } \\
\text { care with } \\
\text { education is key } \\
\text { element on } \\
\text { satisfaction }\end{array}$ & $\begin{array}{l}\text { Earlier position } \\
\text { in the } \\
\text { continuum of } \\
\text { care would } \\
\text { produce greater } \\
\text { benefits; } \\
\text { ironically, in rural } \\
\text { areas, can } \\
\text { typically get an } \\
\text { MRI quicker then } \\
\text { PT services }\end{array}$ & $\begin{array}{l}\text { Main impact is } \\
\text { on freeing up } \\
\text { surgeon's time } \\
\text { by moving the } \\
\text { triaging activity } \\
\text { to the } \\
\text { physiotherapist }\end{array}$ & $\begin{array}{l}\text { No identifiable } \\
\text { sub-population } \\
\text { disproportionally } \\
\text { affected by LBP } \\
\text { although more } \\
\text { women get } \\
\text { treatment then } \\
\text { men }\end{array}$ & $\begin{array}{l}\text { Significant } \\
\text { impact on risk of } \\
\text { worsening } \\
\text { disability and } \\
\text { time off-work } \\
\text { [20]. About } 80 \text { to } \\
90 \% \text { of all cases } \\
\text { are resolved, i.e. } \\
\text { patients } \\
\text { experience a } \\
\text { normal lifestyle } \\
\text { except for the } \\
\text { odd episodic } \\
\text { recurrence }\end{array}$ & $\begin{array}{l}\text { Incidence of LBP } \\
\text { is steady but } \\
\text { proportion of } \\
\text { cases that evolve } \\
\text { to chronic } \\
\text { condition is } \\
\text { increasing; this } \\
\text { process } \\
\text { accelerates access } \\
\text { to treatment } \\
\text { thereby reducing } \\
\text { the risk of the } \\
\text { condition } \\
\text { becoming } \\
\text { chronic. }\end{array}$ & $\begin{array}{l}\text { Patients are } \\
\text { more likely to } \\
\text { participate in } \\
\text { exercise } \\
\text { programs that } \\
\text { reflect their } \\
\text { preferences, } \\
\text { circumstances } \\
\text { and abilities; } \\
\text { recommend } \\
\text { collecting } \\
\text { patient } \\
\text { preferences } \\
\text { before starting } \\
\text { treatment [21] }\end{array}$ & $\begin{array}{l}\text { Requirements for } \\
\text { triaging program: } \\
\text { Cooperation from } \\
\text { surgeons; } \\
\text { Specialized } \\
\text { training for the } \\
\text { physiotherapist }\end{array}$ & $\begin{array}{l}\text { Long-term } \\
\text { impact will be } \\
\text { on the } \\
\text { proportion of } \\
\text { cases that } \\
\text { become chronic } \\
\text { (chronic LBP } \\
\text { affects mobility } \\
\text { which has } \\
\text { psychological } \\
\text { impacts as well } \\
\text { as physical } \\
\text { impacts through } \\
\text { the limitation on } \\
\text { the ability to } \\
\text { exercise) }\end{array}$ \\
\hline
\end{tabular}


Table 4 Key findings by criteria service areas (Continued)

\begin{tabular}{|c|c|c|c|c|c|c|c|c|c|c|c|}
\hline $\begin{array}{l}\text { 3. Rehabilitation } \\
\text { services in the } \\
\text { intensive care } \\
\text { unit }\end{array}$ & $\begin{array}{l}\text { With } \\
\text { physiotherapy, } \\
\text { functional ability } \\
\text { at time of } \\
\text { discharge from } \\
\text { ICU is higher, } \\
\text { leading to } \\
\text { reduced costs } \\
\text { such as multi- } \\
\text { system de- } \\
\text { conditioning } \\
\text { with long- term } \\
\text { bed rest }\end{array}$ & $\begin{array}{l}\text { Impact of ICU } \\
\text { physiotherapy } \\
\text { on QoL is } \\
\text { mainly through } \\
\text { prevention of } \\
\text { problems } \\
\text { resulting from } \\
\text { an ICU stay. } \\
\text { These problems } \\
\text { are a direct } \\
\text { determinant of } \\
\text { where patients } \\
\text { goes next, e.g., } \\
\text { nursing home } \\
\text { or own home }\end{array}$ & $\begin{array}{l}\text { Significant } \\
\text { provider } \\
\text { satisfaction in } \\
\text { this field in } \\
\text { assisting people } \\
\text { to move earlier } \\
\text { along with } \\
\text { greater patient } \\
\text { connection; } \\
\text { physiotherapy is } \\
\text { a constant; } \\
\text { promotes } \\
\text { relationship } \\
\text { building }\end{array}$ & $\begin{array}{l}\text { ICU is extremely } \\
\text { multi-disciplinary; } \\
\text { no practitioner } \\
\text { can act in } \\
\text { isolation and } \\
\text { therefore } \\
\text { coordination } \\
\text { occurs across } \\
\text { disciplines, in this } \\
\text { context, } \\
\text { physiotherapist } \\
\text { chart notes have } \\
\text { a direct impact } \\
\text { on how the } \\
\text { patient is treated } \\
\text { on the ward }\end{array}$ & $\begin{array}{l}\text { PT can affect } \\
\text { LOS in ICU }\end{array}$ & $\begin{array}{l}\text { ICU population is } \\
\text { heterogeneous; } \\
\text { equity not an } \\
\text { issue }\end{array}$ & $\begin{array}{l}\text { Two key areas of } \\
\text { impact: Early } \\
\text { mobility } \\
\text { Ventilator } \\
\text { weaning }\end{array}$ & $\begin{array}{l}\text { Patients are } \\
\text { becoming far } \\
\text { more complex } \\
\text { with co- } \\
\text { morbidities - } \\
\text { physiotherapists } \\
\text { look at patients } \\
\text { holistically versus } \\
\text { possible } \\
\text { fragmentation of } \\
\text { specialized } \\
\text { services }\end{array}$ & $\begin{array}{l}\text { Involves hard } \\
\text { work but no } \\
\text { different than } \\
\text { other PT } \\
\text { services }\end{array}$ & $\begin{array}{l}\text { Specialized } \\
\text { equipment } \\
\text { required }\end{array}$ & $\begin{array}{l}\text { Ability to go } \\
\text { home earlier } \\
\text { with } \\
\text { physiotherapy } \\
\text { service; } \\
\text { however, longer } \\
\text { term utilization is } \\
\text { less likely to be } \\
\text { impacted }\end{array}$ \\
\hline $\begin{array}{l}\text { 4. Physiotherapy } \\
\text { interventions for } \\
\text { chronic disease } \\
\text { management }\end{array}$ & $\begin{array}{l}\text { Service is found } \\
\text { to be sufficiently } \\
\text { cost-effective to } \\
\text { be included in } \\
\text { the coverage } \\
\text { provided by } \\
\text { some privately- } \\
\text { funded } \\
\text { extended health } \\
\text { care plans }\end{array}$ & $\begin{array}{l}\text { Because of the } \\
\text { mobility } \\
\text { concern, the } \\
\text { impact of } \\
\text { physiotherapy } \\
\text { on QoL is } \\
\text { connected } \\
\text { primarily to } \\
\text { increased level } \\
\text { of activity and } \\
\text { functioning. } \\
\text { Many disease } \\
\text { specific } \\
\text { research } \\
\text { findings }\end{array}$ & $\begin{array}{l}\text { Ranges of } \\
\text { improvement } \\
\text { but chronic } \\
\text { disease by } \\
\text { definition will } \\
\text { not be 'curative'; } \\
\text { PT best viewed } \\
\text { as an integral } \\
\text { part of multi- } \\
\text { modal team of } \\
\text { care }\end{array}$ & $\begin{array}{l}\text { Without } \\
\text { physiotherapy, } \\
\text { patients would } \\
\text { be on waitlists } \\
\text { for physician } \\
\text { services or } \\
\text { surgery; assists } \\
\text { with filling gaps }\end{array}$ & $\begin{array}{l}\text { When } \\
\text { physiotherapy } \\
\text { conducted } \\
\text { alongside } \\
\text { physicians, } \\
\text { physicians' } \\
\text { capacity } \\
\text { increases }\end{array}$ & No impact & $\begin{array}{l}\text { Because patients' } \\
\text { problems are } \\
\text { multi-faceted and } \\
\text { require multiple } \\
\text { interventions (e.g. } \\
\text { medication, } \\
\text { surgery), PT role } \\
\text { in designing } \\
\text { exercise } \\
\text { programs that } \\
\text { take all of these } \\
\text { factors into } \\
\text { consideration is } \\
\text { central to overall } \\
\text { effectiveness }\end{array}$ & $\begin{array}{l}\text { Growing problem, } \\
\text { especially with an } \\
\text { aging population }\end{array}$ & $\begin{array}{l}\text { Important to } \\
\text { measure and } \\
\text { track progress } \\
\text { as an incentive }\end{array}$ & $\begin{array}{l}\text { Expertise is } \\
\text { available, } \\
\text { especially if } \\
\text { physiotherapists } \\
\text { are used to plan } \\
\text { and supervise } \\
\text { activities, while } \\
\text { assistants provide } \\
\text { instruction and } \\
\text { oversee } \\
\text { individual } \\
\text { exercise } \\
\text { programs (see: } \\
\text { CLCS model in } \\
\text { community } \\
\text { centres in } \\
\text { Quebec) }\end{array}$ & $\begin{array}{l}\text { Significant } \\
\text { prevention } \\
\text { potential that } \\
\text { can have a large } \\
\text { impact on future } \\
\text { use of resources }\end{array}$ \\
\hline $\begin{array}{l}\text { 5. Rehabilitation } \\
\text { services for } \\
\text { chronic lung } \\
\text { disease }\end{array}$ & $\begin{array}{l}\text { Multidisciplinary, } \\
\text { outpatient } \\
\text { pulmonary rehab } \\
\text { (PR) program } \\
\text { substantially } \\
\text { reduced health } \\
\text { resources use in } \\
\text { patients with } \\
\text { moderate, severe } \\
\text { and very severe } \\
\text { COPD. The mean } \\
\text { incremental cost }\end{array}$ & $\begin{array}{l}\text { PR shown to } \\
\text { improve quality } \\
\text { of life (Rubi; } \\
\text { McCarroll); PR } \\
\text { deals with } \\
\text { physical } \\
\text { function, but } \\
\text { also with the } \\
\text { psychological } \\
\text { aspects } \\
\text { through } \\
\text { education }\end{array}$ & $\begin{array}{l}\text { Patients who } \\
\text { have received } \\
\text { PR often want to } \\
\text { be re-admitted } \\
\text { after their next } \\
\text { exacerbation }\end{array}$ & $\begin{array}{l}\text { There is poor } \\
\text { continuum of } \\
\text { care for COPD } \\
\text { patients. Current } \\
\text { care is focused } \\
\text { on responding } \\
\text { to exacerbations }\end{array}$ & $\begin{array}{l}\text { Use of PR } \\
\text { results in less } \\
\text { exacerbations, } \\
\text { fewer ER visits } \\
\text { and reduced } \\
\text { number of } \\
\text { unscheduled } \\
\text { GP visits }\end{array}$ & $\begin{array}{l}\text { COPD does not } \\
\text { disproportionally } \\
\text { affect any } \\
\text { specific } \\
\text { 'disadvantaged' } \\
\text { group }\end{array}$ & $\begin{array}{l}\text { There is strong } \\
\text { evidence } \\
\text { demonstrating a } \\
\text { reduction in } \\
\text { dyspnea, } \\
\text { increased } \\
\text { exercise } \\
\text { tolerance, } \\
\text { improved health } \\
\text { related quality of } \\
\text { life and cost- } \\
\text { effectiveness [23] }\end{array}$ & $\begin{array}{l}\text { COPD is a } \\
\text { significant chronic } \\
\text { disease in terms } \\
\text { of incidence and } \\
\text { prevalence: fourth } \\
\text { or fifth leading } \\
\text { cause of death }\end{array}$ & $\begin{array}{l}\text { Patients } \\
\text { typically want } \\
\text { to return to } \\
\text { treatment }\end{array}$ & $\begin{array}{l}\text { No specialized } \\
\text { resources needed; } \\
\text { physiotherapists } \\
\text { can be trained } \\
\text { quickly in the } \\
\text { specifics of this } \\
\text { service; exercise } \\
\text { equipment used is } \\
\text { standard }\end{array}$ & $\begin{array}{l}\text { Patients receiving } \\
\text { PR are, in the } \\
\text { long run, more } \\
\text { likely to stay at } \\
\text { home longer, } \\
\text { therefore } \\
\text { postponing } \\
\text { institutionalization }\end{array}$ \\
\hline
\end{tabular}


Table 4 Key findings by criteria service areas (Continued)

\begin{tabular}{|c|c|c|c|c|c|c|c|c|c|c|c|}
\hline $\begin{array}{l}\text { 6. Rehabilitation } \\
\text { services for } \\
\text { cardiovascular } \\
\text { disease }\end{array}$ & $\begin{array}{l}\text { Outpatient CR } \\
\text { less expensive } \\
\text { than inpatient } \\
\text { yet similar } \\
\text { effectiveness }\end{array}$ & $\begin{array}{l}\text { CR significantly } \\
\text { improved QoL } \\
\text { scores, reduced } \\
\text { depression and } \\
\text { had positive } \\
\text { effect on } \\
\text { psychosocial } \\
\text { measures }\end{array}$ & $\begin{array}{l}\text { Service can be } \\
\text { fully tailored to } \\
\text { the client's } \\
\text { situation }\end{array}$ & $\begin{array}{l}\text { Clients come } \\
\text { from diagnosis } \\
\text { of cardiovascular } \\
\text { condition then } \\
\text { transition to } \\
\text { local, ongoing, } \\
\text { community } \\
\text { services; CR } \\
\text { plays an } \\
\text { essential role in } \\
\text { facilitating this } \\
\text { transition }\end{array}$ & $\begin{array}{l}\text { Impact on the } \\
\text { use of other } \\
\text { health services } \\
\text { is not } \\
\text { immediate } \\
\text { (except for } \\
\text { length of } \\
\text { hospital stay) }\end{array}$ & $\begin{array}{l}\text { Women, the } \\
\text { elderly, ethnic } \\
\text { minority groups } \\
\text { access CR less. } \\
\text { Very little } \\
\text { information on } \\
\text { why subgroups } \\
\text { have lower rates } \\
\text { of access }\end{array}$ & $\begin{array}{l}\text { CR reduces the } \\
\text { risk of cardiac } \\
\text { and general } \\
\text { mortality rates } \\
\text { by 25-30\% }\end{array}$ & $\begin{array}{l}\text { There is a } \\
\text { growing referral } \\
\text { rate AND a } \\
\text { growing uptake } \\
\text { rate because of } \\
\text { increased } \\
\text { awareness } \\
\text { (referral rate) and } \\
\text { improvements in } \\
\text { services (uptake } \\
\text { rate) }\end{array}$ & $\begin{array}{l}\text { The services } \\
\text { are mostly } \\
\text { about teaching } \\
\text { so there is no } \\
\text { physical pain. } \\
\text { Changes in } \\
\text { lifestyle being } \\
\text { promoted can } \\
\text { be difficult to } \\
\text { adopt }\end{array}$ & None noted & $\begin{array}{l}\text { Services reduce } \\
\text { the likelihood of } \\
\text { recurrence of the } \\
\text { problems and } \\
\text { reduces the } \\
\text { seriousness of } \\
\text { future problems }\end{array}$ \\
\hline $\begin{array}{l}\text { 7. Rehabilitation } \\
\text { services } \\
\text { following joint } \\
\text { arthroplasty }\end{array}$ & $\begin{array}{l}\text { When comparing } \\
\text { the cost- } \\
\text { effectiveness of } \\
\text { an accelerated } \\
\text { perioperative care } \\
\text { and rehabilitation } \\
\text { protocol with } \\
\text { that of a more } \\
\text { standard protocol } \\
\text { for patients } \\
\text { treated with total } \\
\text { hip arthroplasty, } \\
\text { beginning from } \\
\text { the first visit } \\
\text { before the } \\
\text { operation to one } \\
\text { year } \\
\text { postoperatively, a } \\
\text { study found the } \\
\text { accelerated } \\
\text { intervention to } \\
\text { be more effective } \\
\text { with an average } \\
\text { of } \$ 4000 \\
\text { reduction in } \\
\text { treatment costs } \\
\text { with a } 0.08 \text { QALY } \\
\text { gain; also more } \\
\text { cost-effective for } \\
\text { total knee } \\
\text { arthroplasty with } \\
\text { no difference in } \\
\text { QALYY [24] }\end{array}$ & $\begin{array}{l}\text { PT provides } \\
\text { both earlier } \\
\text { functionality and } \\
\text { a better end } \\
\text { point }\end{array}$ & $\begin{array}{l}\text { Postoperative, } \\
\text { active physical } \\
\text { therapy increases } \\
\text { satisfaction and } \\
\text { helps to meet } \\
\text { patient } \\
\text { expectations [25] }\end{array}$ & $\begin{array}{l}\text { Impact on } \\
\text { continuum of } \\
\text { care comes from } \\
\text { accelerating } \\
\text { patient's } \\
\text { progression } \\
\text { through the care } \\
\text { process }\end{array}$ & $\begin{array}{l}\text { Will reduce } \\
\text { doctor visits }\end{array}$ & $\begin{array}{l}\text { More difficult to } \\
\text { access PT } \\
\text { services in rural } \\
\text { settings }\end{array}$ & $\begin{array}{l}\text { Using team } \\
\text { approach, } \\
\text { patients had } \\
\text { large } \\
\text { improvements in } \\
\text { outcome } \\
\text { measures during } \\
\text { the } \\
\text { rehabilitation } \\
\text { stay and 6- } \\
\text { month follow-up } \\
\text { [26] }\end{array}$ & $\begin{array}{l}\text { Joint arthroplasty } \\
\text { volume is driven } \\
\text { by demographics }\end{array}$ & $\begin{array}{l}\text { High } \\
\text { acceptability }\end{array}$ & $\begin{array}{l}\text { No significant HR } \\
\text { or equipment } \\
\text { challenges }\end{array}$ & $\begin{array}{l}\text { No evidence of } \\
\text { impact on future } \\
\text { use of health } \\
\text { care services (3 } \\
\text { +years) }\end{array}$ \\
\hline
\end{tabular}


Table 4 Key findings by criteria service areas (Continued)

\begin{tabular}{|c|c|c|c|c|c|c|c|c|c|c|c|}
\hline $\begin{array}{l}\text { 8. Rehabilitation } \\
\text { services } \\
\text { following stroke }\end{array}$ & $\begin{array}{l}\text { Very early } \\
\text { mobilisation } \\
\text { (VEM) more cost- } \\
\text { effective than } \\
\text { standard care } \\
\text { and improved } \\
\text { outcomes }\end{array}$ & $\begin{array}{l}\text { Research } \\
\text { findings still } \\
\text { lacking; recent } \\
\text { innovations in } \\
\text { diagnosis, } \\
\text { management, } \\
\text { and } \\
\text { rehabilitation } \\
\text { have resulted in } \\
\text { measurable } \\
\text { improvements } \\
\text { in clinical and } \\
\text { functional } \\
\text { outcomes after } \\
\text { acute stroke; } \\
\text { however, } \\
\text { despite } \\
\text { improvements } \\
\text { in medical } \\
\text { management, } \\
\text { quality of life is } \\
\text { not necessarily } \\
\text { improving post } \\
\text { stroke [27] }\end{array}$ & $\begin{array}{l}\text { Programs are } \\
\text { meant to be } \\
\text { patient-centered: } \\
\text { this is the goal; } \\
\text { limitation is in } \\
\text { resource } \\
\text { constraints } \\
\text { which reduces } \\
\text { ability to } \\
\text { customize } \\
\text { treatment plans }\end{array}$ & $\begin{array}{l}\text { Key component } \\
\text { of the continuum } \\
\text { of care; If there is } \\
\text { not sufficient } \\
\text { physiotherapy } \\
\text { services LOS is } \\
\text { longer and/or the } \\
\text { patient does not } \\
\text { do as well }\end{array}$ & $\begin{array}{l}\text { Very limited } \\
\text { impact on the } \\
\text { concurrent } \\
\text { utilization of } \\
\text { other services }\end{array}$ & $\begin{array}{l}\text { Increased odds of } \\
\text { problems from a } \\
\text { past stroke } \\
\text { associated with } \\
\text { failure to access } \\
\text { OT/PT services, } \\
\text { lower monthly } \\
\text { income, and age }\end{array}$ & $\begin{array}{l}\text { Comparing } \\
\text { specialized } \\
\text { outpatient } \\
\text { therapy to no } \\
\text { treatment, } 14 \\
\text { RCTs found that } \\
\text { therapy-based } \\
\text { outpatient rehab } \\
\text { was associated } \\
\text { with a reduction } \\
\text { in the odds of } \\
\text { poor outcome } \\
\text { and increased } \\
\text { daily living and } \\
\text { personal activity } \\
\text { scores }\end{array}$ & $\begin{array}{l}\text { Stroke is a } \\
\text { significant } \\
\text { condition in } \\
\text { terms of } \\
\text { incidence; } \\
\text { physiotherapy is } \\
\text { an integral part } \\
\text { of its treatment }\end{array}$ & $\begin{array}{l}\text { Stroke causes } \\
\text { fear in patients, } \\
\text { which increases } \\
\text { treatment } \\
\text { acceptance rate; } \\
\text { physiotherapy } \\
\text { focuses on } \\
\text { restoring } \\
\text { physical function } \\
\text { and in so doing, } \\
\text { provides positive } \\
\text { feedback }\end{array}$ & $\begin{array}{l}\text { Requires more } \\
\text { rehab beds and/or } \\
\text { specialized units }\end{array}$ & $\begin{array}{l}\text { Improved } \\
\text { physical function } \\
\text { and has direct } \\
\text { impact on social } \\
\text { function; } \\
\text { minimizes the } \\
\text { future use of } \\
\text { health care } \\
\text { services }\end{array}$ \\
\hline $\begin{array}{l}\text { 9. Physiotherapy } \\
\text { services in the } \\
\text { emergency } \\
\text { department }\end{array}$ & $\begin{array}{l}\text { Can reduce LOS } \\
\text { for some } \\
\text { patients; } \\
\text { facilitates flow in } \\
\text { the ER }\end{array}$ & $\begin{array}{l}\text { Services } \\
\text { address fear } \\
\text { and uncertainty } \\
\text { around risks } \\
\text { when } \\
\text { discharged }\end{array}$ & $\begin{array}{l}\text { Potentially better } \\
\text { client satisfaction: } \\
\text { less pain, reduces } \\
\text { short-term } \\
\text { disability, } \\
\text { improves } \\
\text { function and } \\
\text { safety }\end{array}$ & $\begin{array}{l}\text { Important } \\
\text { 'triaging' role in } \\
\text { the continuum }\end{array}$ & $\begin{array}{l}\text { Sizeable } \\
\text { impact on rate } \\
\text { of return visits } \\
\text { to emergency }\end{array}$ & $\begin{array}{l}\text { Rate of } \\
\text { emergency visits } \\
\text { not clearly } \\
\text { related to being } \\
\text { part of any } \\
\text { disadvantaged } \\
\text { populations }\end{array}$ & $\begin{array}{l}\text { At system and } \\
\text { provider levels, } \\
\text { there is limited } \\
\text { research } \\
\text { evidence on the } \\
\text { value of an } \\
\text { emergency } \\
\text { department } \\
\text { physiotherapy } \\
\text { service; at patient } \\
\text { level, there is } \\
\text { high-level } \\
\text { evidence of } \\
\text { benefits in terms } \\
\text { of improved pain } \\
\text { control and } \\
\text { reduced disability } \\
\text { in the short term }\end{array}$ & $\begin{array}{l}\text { There is an } \\
\text { increase in ED } \\
\text { attendances, } \\
\text { therefore an } \\
\text { increased need } \\
\text { for emergency PT } \\
\text { services }\end{array}$ & $\begin{array}{l}\text { Sometimes } \\
\text { 'forces' the } \\
\text { realization that } \\
\text { the patient is at } \\
\text { a time of life } \\
\text { where there is a } \\
\text { loss of } \\
\text { independence } \\
\text { and a need for } \\
\text { mobility aids or } \\
\text { assistance }\end{array}$ & $\begin{array}{l}\text { Increased volume } \\
\text { comes with a } \\
\text { need for } \\
\text { observation beds } \\
\text { and sub-acute } \\
\text { beds }\end{array}$ & $\begin{array}{l}\text { Patients are } \\
\text { flagged earlier for } \\
\text { present and } \\
\text { potential } \\
\text { problems and } \\
\text { can be followed/ } \\
\text { assisted in the } \\
\text { community }\end{array}$ \\
\hline
\end{tabular}


Table 4 Key findings by criteria service areas (Continued)

\begin{tabular}{|c|c|c|c|c|c|c|c|c|c|c|c|}
\hline $\begin{array}{l}\text { 10. Home based } \\
\text { rehabilitation } \\
\text { services }\end{array}$ & $\begin{array}{l}\text { Significant cost } \\
\text { aversion; } \\
\text { mobility } \\
\text { assessment, } \\
\text { keeping people } \\
\text { independent in } \\
\text { their homes; } \\
\text { prevention of } \\
\text { falls and } \\
\text { providing a safe } \\
\text { environment } \\
\text { within the home } \\
\text { context }\end{array}$ & $\begin{array}{l}\text { Impact of PT } \\
\text { can include } \\
\text { increased social } \\
\text { interaction; } \\
\text { improved } \\
\text { personal and } \\
\text { domestic } \\
\text { activities; } \\
\text { improved } \\
\text { health status; } \\
\text { improved } \\
\text { subjective } \\
\text { quality of life; } \\
\text { reduced } \\
\text { caregiver } \\
\text { burden }\end{array}$ & $\begin{array}{l}\text { Patient } \\
\text { satisfaction is } \\
\text { clear (but } \\
\text { typically is not } \\
\text { tracked by formal } \\
\text { instruments); one } \\
\text { measure of } \\
\text { satisfaction is that } \\
\text { the clients pay } \\
\text { for subsequent } \\
\text { visits; verbal } \\
\text { feedback from } \\
\text { clients is very } \\
\text { positive; while } \\
\text { anecdotal, the } \\
\text { high level of } \\
\text { satisfaction is } \\
\text { clear }\end{array}$ & $\begin{array}{l}\text { Service is } \\
\text { extremely } \\
\text { relevant to } \\
\text { service } \\
\text { integration; big } \\
\text { gap in the } \\
\text { continuum of } \\
\text { care from } \\
\text { hospital to } \\
\text { home; a lot of } \\
\text { people } \\
\text { discharged from } \\
\text { the hospital and } \\
\text { in need of } \\
\text { home-based } \\
\text { service but are } \\
\text { not receiving it } \\
\text { or receive it in a } \\
\text { very limited } \\
\text { manner, i.e., no } \\
\text { active rehab } \\
\text { post discharge, } \\
\text { rather patients } \\
\text { are given a } \\
\text { walker or basic } \\
\text { level of } \\
\text { information }\end{array}$ & $\begin{array}{l}\text { Reduces LOS } \\
\text { and } \\
\text { hospitalisations }\end{array}$ & $\begin{array}{l}\text { Inequities exist } \\
\text { between } \\
\text { Provinces: those } \\
\text { without financial } \\
\text { means do not } \\
\text { have access to } \\
\text { home-based } \\
\text { rehab services in } \\
\text { some Provinces; } \\
\text { those with } \\
\text { chronic } \\
\text { conditions are } \\
\text { more vulnerable } \\
\text { and need more } \\
\text { follow-up; } \\
\text { currently, there is } \\
\text { no support from } \\
\text { the public system } \\
\text { to help these } \\
\text { individuals }\end{array}$ & $\begin{array}{l}\text { When comparing } \\
\text { adults } 70 \text { years or } \\
\text { older with one or } \\
\text { more functional } \\
\text { problems who } \\
\text { received a home- } \\
\text { based } \\
\text { programme of } \\
\text { occupational } \\
\text { therapy and } \\
\text { physiotherapy to } \\
\text { a control group, } \\
\text { a significant } \\
\text { reduction in } \\
\text { mortality rate } \\
\text { was found (5.6\% } \\
\text { vs 13.2\%); } \\
\text { individuals with a } \\
\text { moderate risk of } \\
\text { mortality in the } \\
\text { intervention } \\
\text { groups also } \\
\text { showed a } \\
\text { significant } \\
\text { reduction at } \\
16.7 \% \text { vs. 28.3\% } \\
\text { [28] }\end{array}$ & $\begin{array}{l}\text { Home-based } \\
\text { therapy increases } \\
\text { access, in } \\
\text { particular for } \\
\text { patients with } \\
\text { greater medical } \\
\text { complexities }\end{array}$ & $\begin{array}{l}\text { Main issue is } \\
\text { the payment } \\
\text { required for } \\
\text { services }\end{array}$ & $\begin{array}{l}\text { Have to have the } \\
\text { right provider: not } \\
\text { every } \\
\text { physiotherapist } \\
\text { can provide this } \\
\text { service; broad } \\
\text { experience base is } \\
\text { required to be } \\
\text { effective and } \\
\text { proficient; } \\
\text { therapist works on } \\
\text { their own which } \\
\text { means there are } \\
\text { no second } \\
\text { opinions; some } \\
\text { anxiety in } \\
\text { providing in- } \\
\text { home services } \\
\text { and worker safety } \\
\text { can be a concern }\end{array}$ & $\begin{array}{l}\text { Home-based } \\
\text { services are } \\
\text { expensive with } \\
\text { respect to time to } \\
\text { travel and low } \\
\text { volume however } \\
\text { this needs to be } \\
\text { considered in } \\
\text { light of potential } \\
\text { decrease in } \\
\text { utilization of } \\
\text { future service } \\
\text { needs; in the } \\
\text { long term, this is } \\
\text { a very efficient } \\
\text { use of societal } \\
\text { resources }\end{array}$ \\
\hline $\begin{array}{l}11 . \\
\text { Rehabilitation } \\
\text { services for falls }\end{array}$ & $\begin{array}{l}\text { Treatment for } \\
\text { falls was } 1.8 \\
\text { times more } \\
\text { costly than } \\
\text { implementing a } \\
\text { fall prevention } \\
\text { program }\end{array}$ & $\begin{array}{l}\text { Specialized } \\
\text { balance } \\
\text { program for } \\
\text { women with } \\
\text { osteoporosis } \\
\text { significantly } \\
\text { improved } \\
\text { quality of life, } \\
\text { physical } \\
\text { function, } \\
\text { symptoms, } \\
\text { social } \\
\text { interaction and } \\
\text { overall } \\
\text { wellbeing [29] }\end{array}$ & $\begin{array}{l}\text { Falls prevention } \\
\text { programming is } \\
\text { a new field, to } \\
\text { date has not } \\
\text { drawn adequate } \\
\text { attention }\end{array}$ & $\begin{array}{l}\text { Not really part of } \\
\text { a continuum of } \\
\text { care in most } \\
\text { cases }\end{array}$ & $\begin{array}{l}\text { Fall prevention } \\
\text { service does } \\
\text { not reduce } \\
\text { client's use of } \\
\text { other services; } \\
\text { greatest } \\
\text { impact on } \\
\text { future service } \\
\text { use }\end{array}$ & $\begin{array}{l}\text { Programs tend } \\
\text { to target seniors } \\
\text { and diabetics }\end{array}$ & $\begin{array}{l}\text { Exercise } \\
\text { program } \\
\text { significantly } \\
\text { reduces the risk } \\
\text { of death, of } \\
\text { falling and } \\
\text { hospitalisation } \\
\text { or transfer to a } \\
\text { nursing home }\end{array}$ & $\begin{array}{l}\text { Need to get out } \\
\text { in front to } \\
\text { provide } \\
\text { prospective } \\
\text { services instead } \\
\text { of providing } \\
\text { service } \\
\text { retrospectively }\end{array}$ & $\begin{array}{l}\text { No physical } \\
\text { risks or } \\
\text { discomfort but } \\
\text { psychological } \\
\text { 'discomfort' as } \\
\text { fall prevention } \\
\text { associated with } \\
\text { a loss of } \\
\text { independence }\end{array}$ & $\begin{array}{l}\text { More awareness } \\
\text { with health care } \\
\text { professionals } \\
\text { generally }\end{array}$ & $\begin{array}{l}\text { Substantial } \\
\text { impact especially } \\
\text { in the subset of } \\
\text { cases where falls } \\
\text { can be avoided }\end{array}$ \\
\hline
\end{tabular}


Table 4 Key findings by criteria service areas (Continued)

\begin{tabular}{|c|c|c|c|c|c|c|c|c|c|c|c|}
\hline $\begin{array}{l}12 . \\
\text { Rehabilitation } \\
\text { services for } \\
\text { pediatrics }\end{array}$ & $\begin{array}{l}\text { Getting right } \\
\text { programs in } \\
\text { place early can } \\
\text { make a lifelong } \\
\text { difference in } \\
\text { health outcomes } \\
\text { and lead to very } \\
\text { significant } \\
\text { savings }\end{array}$ & $\begin{array}{l}\text { Movement is } \\
\text { freedom; for } \\
\text { children who } \\
\text { have difficulty } \\
\text { getting } \\
\text { involved in } \\
\text { activities, these } \\
\text { services open } \\
\text { opportunity for } \\
\text { participation }\end{array}$ & $\begin{array}{l}\text { Physiotherapist is } \\
\text { the health care } \\
\text { professional in } \\
\text { closest contact } \\
\text { with the patient } \\
\text { and his/her } \\
\text { family; } \\
\text { relationship that } \\
\text { develops is } \\
\text { potentially unlike } \\
\text { any other health } \\
\text { care profession; } \\
\text { very personal in } \\
\text { nature; } \\
\text { physiotherapists } \\
\text { best understand } \\
\text { the child's } \\
\text { disability and so } \\
\text { can relate very } \\
\text { well; becomes } \\
\text { very strong } \\
\text { advocates for the } \\
\text { patient and } \\
\text { family }\end{array}$ & $\begin{array}{l}\text { The service } \\
\text { definitely } \\
\text { addresses a gap; } \\
\text { if this service was } \\
\text { not in place, by } \\
\text { the time the } \\
\text { child reached } \\
\text { adulthood they } \\
\text { would be so far } \\
\text { behind in their } \\
\text { development } \\
\text { they could never } \\
\text { catch up }\end{array}$ & $\begin{array}{l}\text { Some surgery } \\
\text { avoidance; } \\
\text { some } \\
\text { reduction in } \\
\text { GP visits }\end{array}$ & $\begin{array}{l}\text { Many } \\
\text { disadvantaged } \\
\text { groups do not } \\
\text { typically go to the } \\
\text { hospital for } \\
\text { services; if rehab } \\
\text { services are in the } \\
\text { community and/ } \\
\text { or school or } \\
\text { community } \\
\text { centre, access to } \\
\text { health care is } \\
\text { more likely: } \\
\text { practitioners will } \\
\text { often see } \\
\text { individuals who } \\
\text { have not } \\
\text { accessed any } \\
\text { other service in } \\
\text { the system }\end{array}$ & $\begin{array}{l}\text { Many studies } \\
\text { have shown } \\
\text { effectiveness; } \\
\text { studies are } \\
\text { typically small, } \\
\text { but results are } \\
\text { consistent across } \\
\text { conditions }\end{array}$ & $\begin{array}{l}\text { Children do not } \\
\text { respond as well in } \\
\text { adult facilities }\end{array}$ & $\begin{array}{l}\text { Typically, very } \\
\text { well received }\end{array}$ & $\begin{array}{l}\text { Baseline services } \\
\text { are not a } \\
\text { challenge - new } \\
\text { grads can do this }\end{array}$ & $\begin{array}{l}\text { Early intervention } \\
\text { has significant } \\
\text { impact on } \\
\text { reducing future } \\
\text { utilization of } \\
\text { services, including } \\
\text { prevention of } \\
\text { secondary } \\
\text { surgeries }\end{array}$ \\
\hline
\end{tabular}


adults [33], ankle fractures [34], stroke [35], heart failure [36], breast cancer [37], and recovery from hip replacement surgery [38]. For such conditions, home based interventions have been shown to lower mortality rates related to falls $[28,39]$ and the risk and rate of falls in older adults [40], reduce the number of nursing home admissions and hospitalisations, and decrease hospital length of stay.

Home-based physiotherapy programs are critical to service integration, providing a much-needed link between hospital and home. Home-based physiotherapy services can also help with a social issue: social isolation is often an issue for older clients and clients with more complex conditions; with physiotherapists providing inhome care, patients receive regular visits and consistent monitoring and follow-up.

\section{Intensive Care Units (ICUs)}

The most common use of physiotherapy in ICU is to improve function for patients on mechanical ventilation [41]. Improving function has been shown to reduce dependency and promote earlier weaning, which in turn decreases hospital length of stay and increases quality of life [42-44]. With a reduction in hospital length of stay, along with increased function and fewer patient complications, physiotherapy treatment is highly cost-effective, reducing both the burden on acute care services and future health care service use $[45,46]$. Further, because treatment prevents critical weakness and increases functional ability $[45,47,48]$ patients are less likely to be discharged to a care facility and are more likely to return to their home.

\section{Cardiovascular rehabilitation}

Cardiac rehabilitation services support patients when transitioning from hospital to the community by helping with linkages to services within the community. This helps to ensure that client care continues after discharge. Such linkages also help to promote social engagement, adoption of healthy behaviors and provide support for self-managed care. Along with a resulting reduction in hospitalisation rates [49] and improvements to physical activity, smoking cessation rates, systolic blood pressure, weight loss and total cholesterol [50,51], cardiovascular physiotherapy services also provide a means of enhancing the surveillance of higher risk patients while providing personalized, tailored care that leads to improved psychosocial function.

\section{Emergency}

Physiotherapists in emergency departments can improve pain control [52] and reduce short-term disability [53]. Early access to physiotherapy for this purpose can impact current and future use of health care services.
Physiotherapists also aid in discharge planning by providing community program information and recommendations for mobility aids. Such assistance facilitates the continuation of care which in turn can alleviate patients' fear of the acute event reoccurring while supporting a safe return to the home and community.

Emergency department physiotherapy programs can also decrease hospital length of stay and wait-times, in particular for minor musculoskeletal injuries [54]. Further since emergency departments are often a patient's first point of care, clients who would benefit from physiotherapy interventions can be flagged early on in the care process directly impacting current and future use of health care services.

\section{Stroke}

Research shows that physiotherapy services for stroke patients aid in the prevention of subsequent acute events while supporting a patient's ability to live independently $[55,56]$. Physiotherapy services were also found to be a key component in the continuum of care, supporting patients in their transition from hospital to home [35]. This is particularly true when treatment is provided early and through a specialized stroke unit [56-58], with a dose-dependent effect being present [51]. High intensity physiotherapy programs, task-specific therapies and individual discharge planning all contribute to improved outcomes.

Outpatient physiotherapy programs for stroke patients are also effective. It was found that when outpatient rehabilitation programs were reduced, the length of stay in hospital increased along with rehospitalisation rates and overall costs $[59,60]$.

\section{Musculoskeletal conditions (MSK)}

With programs focusing on client self-management and independence, physiotherapy services are highly valued as an effective tool in the promotion of injury recovery and prevention of acute events [61]. Furthermore, there is a clear, positive relationship between increased physical functioning and improved quality of life.

While the initial costs of physiotherapists treating MSK patients are higher because of the requirement for experienced therapists, patients tend to require fewer visits over time. Care costs can be further reduced by using physiotherapists in triaging of patients: experienced physiotherapists can act as gatekeepers to surgical care, providing appropriate assessment and management of the patient's condition [62-64].

\section{Low back pain}

Physiotherapy for patients with low back pain is highly effective in reducing both acute and chronic pain while significantly limiting the risk of increased disability and 
chronic conditions [65-67]. Research suggests that between 80 to 90 percent of all lower back cases can be resolved through participation in rehabilitation programs. Rehabilitation programs are also cost-effective [68-71]. Prompt access to a dedicated physiotherapist for new cases of low back pain, in particular for high-risk patients, often pays for itself by reducing the burden on other health care services and promoting self-managed care. Brief, simple and early interventions that include providing information, reassurance and encouragement to engage in regular physical activity have resulted in economic gains measured one year after patients received the intervention, with no long-term negative effects [71].

Physiotherapists can also assist in the triaging of patients to ensure that only those requiring an MRI and a surgeon consult receive a referral for such. Acting as a gatekeeper to surgical care, physiotherapists are able to reduce patient treatment costs and significantly impact surgical wait-times.

\section{Joint arthroplasty}

Overall, effectiveness studies indicate that patients who underwent joint arthroplasty and participated in physiotherapy programs experienced improved outcomes [72] with the greatest health gains achieved from early intervention such as starting rehabilitation 24-hours postsurgery [73]. Benefits included a reduction in pain and an increase in joint motion range, strength and balance $[73,74]$; short-term functional milestones were also attained within a shorter timeframe [24,75]. Early intervention had a positive impact on the length of hospital stays resulting in programs that are highly cost-effective $[24,76,77]$. Overall, inclusion of physiotherapy services in the care continuum had a significant impact on treatment costs [78]. Discharging patients direct to home with supportive therapy was also found to be more costeffective than remaining in hospital with no difference found in health outcomes.

\section{Chronic diseases}

There is strong support for the use of physiotherapy in the prevention and treatment of chronic diseases, including hypertension, emphysema, type II diabetes and obesity [79-84]. Studies have shown that patients who participated in individualized exercise programs had fewer emergency readmissions and physician visits and greater quality of life than patients in usual care. Physiotherapy programs also facilitate participation in community programs that enhance and maintain physical wellbeing, and this in turn can significantly impact future use of health care services. Physiotherapy is an integral part of the inter-professional team in the management of patients with chronic diseases.

\section{Falls}

Physiotherapy is a highly effective tool in the prevention of falls and fall-related injuries both in hospital [85], as well as in the community [86-88]. In the community, the effectiveness of physiotherapy programs is significant with services improving the strength, motor function and balance in older adults who had previously experienced a fall event [89]. These effects contribute to reduced mortality rates, rates of hospitalisation and transfers to a nursing home allowing individuals to live independently in their homes. Similarly, the implementation of a falls-prevention program in an orthopaedic hospital can result in a significant decrease in fall incidence [85], fall-related morbidity and service costs.

Quality of life measures indicate that participation in a falls-prevention program improves a patient's confidence and reduces the fear of falling that often restricts overall physical activity [90].

\section{Chronic lung disease}

There is strong evidence to support the effectiveness of pulmonary rehabilitation services for patients with chronic lung disease, with program participation correlated with decreased rates of dyspnea, exacerbations, and emergency room and physician visits [23,91,92]. Physiotherapy services were found to be cost-effective [93-98] and in some cases a program's net cost was negative (i.e. the program produced net savings): for patients participating in outpatient pulmonary rehab programs, evidence suggests that patient total health resource use is lower compared to usual care. Rehabilitation programs also decreased medication use, the number of ICU admissions over time, and assisted patients in managing their condition, enabling them to remain in their homes longer [99].

\section{Discussion}

In the context of choices that must be made because not all activities can be carried on as they were due to financial restrictions, information about the value of any given intervention is very useful [100]. A common framework for generating such information is economic evaluation where the cost per Quality-Adjusted-LifeYear (QALY) gained through a given intervention is estimated. The estimated cost per QALY gained however only addresses the impact on the life expectancy and on the quality of life of the clients or patients. In making decisions about allocating limited funding, decisionmakers typically consider other objectives in addition to the direct health impact, with equity and access, for example, being often cited [101]. Moreover, economic evaluation is focused on specific end-points which are typically directly related to the condition, or potential condition, being addressed, for example, the extent to 
which physiotherapy services would impact a specific measurement of the progress of juvenile idiopathic arthritis. Because of these limitations, when the CPA decided to address what they felt was a gap in the available information on the value of physiotherapy services, it made the decision to address this gap through the application of MCDA. The overarching thinking behind this decision was that, as healthcare organizations face increasingly tougher choices, the limitations of QALYs as a resource allocation tool will push organizations toward more formal resource allocation frameworks that use MCDA in their evaluation of alternatives and physiotherapy services will be more likely to receive fair consideration if the health care organizations have access to accurate information. PBMA would be one of these frameworks. The choice of MCDA was not primarily guided by the relative level of difficulty in implementing a QALY approach versus MCDA. There was what was perceived as a shortcoming in information on the value of physiotherapy services and it was decided to put effort in the MCDA approach provided a greater potential for impact.

The result was a comprehensive report summarizing the value of each of twelve areas of physiotherapy services with respect to each of eleven criteria that were thought to represent all relevant considerations in making decisions about funding involving those services. Some key findings in terms of benefits of physiotherapy services are presented in this paper. It must be recognized that this paper is not reporting on an implementation of MCDA, or of a prioritization exercise. In fact, what the CPA has done is supply health care organizations in Canada and elsewhere with a base of research work necessary for the implementation of MCDA, as part of a resource allocation framework such as PBMA. The findings can be used as a starting point within any local MCDA implementation. It is not the role of the CPA to contextualize the information, assign weights to the criteria, or even suggest that only the criteria listed here should be used, or to actually rate the impact of service volume changes. These steps are the responsibility of local health care organizations. An organization that decides to implement the MCDA framework to guide resource allocation would have to: 1 ) determine locally relevant criteria and weight them (these could be different than the criteria used in this study but it is not expected that there would be significant differences); 2) identify possible service volume change options that make sense in their context (which depends on the existing mix and volume of services provided); 3) assess the impact of each option on the basis of the selected criteria (this is where the information contained in the CPA report comes into play and provides a necessary starting point, i.e. necessary but not sufficient information). Note that the breakdown of areas of practice may not perfectly fit a given local context, in which case, the relevant areas from the twelve used here can be combined; and 4) rank the options and make decisions. All these steps are standard practice in most prioritization framework, and are part of the PBMA, for example.

Our objective here was not to provide one more case of PBMA implementation but to address a common criticism of PBMA or any other process that includes MCDA: that the required information is either not available or too difficult to obtain making such processes unimplementable and therefore only theoretical constructs. . In terms of information generation, the literature review posed no unusual challenge. As was expected, in the grid of criteria by service area, many of the cells were left blank after the review. The recruitment of experts was done by the CPA and didn't seem very difficult for two reasons: this was a project of the CPA and many members are very supportive of their organization and it is a project that many members can relate to and specifically support. Furthermore, the demands are not overly burdensome as each expert was asked to participate in one or two calls of one to two hour each. What is more challenging is explaining to the experts what is needed from them which is to provide a response to the best of their knowledge and not limit their answers to what they know is research evidencewe really wanted their expert opinion. While this did not come naturally to some of the experts involved, all ended up contributing as was needed. Putting together a validation committee was no more challenging than recruiting experts for the same reasons. And just as was the case with the experts, it is necessary to have a full explanation of the process and some basic training in MCDA before the committee can start to work. The main challenge with validating the local data to the national level was understanding how much of the expert opinions were shaped by unique local circumstances. This was addressed by first identifying where this might be the case, going back to the local expert for further information, and then reconvening the validation committee. The key lessons from this experience were: 1) there has to be experts that buy into what is being done, reluctant participation would defeat the process; 2) explanation of the process and its goals and basic training is necessary before the experts can be asked questions. Finally, it must always be remembered that the ultimate goal is to obtain the best existing information, sometimes experts feel uncomfortable with expressing their opinion in response to a question but if it is the only available information then it becomes the best existing information. In our project, we found some initial hesitation in some cases but all experts were able to overcome it. The main limitation of this paper and the 
supporting report is the extent of the resources available for this project. For many criteria, the principal source of evidence was expert opinion and this was provided on a strictly voluntary basis. There was sufficient input into the process to produce validated results but, without a doubt, more resources would have produced a more refined report. However, a benefit of the MCDA approach is the transparent nature of the process which allows ongoing updating of the results. As new studies are published or as more experts can devote time to this analysis, findings can be continually updated, by area of service or by criterion. And further areas of service can be added.

\section{Conclusion}

As the growth in public health care funding slows, more difficult choices about what to fund and what not to fund must be made. In this context, relevant and accurate information about the marginal value of any health care interventions is essential for proper resource management. MCDA can be a very effective means of producing such valuations which can then be used in whatever priority setting process is implemented. However MCDA requires evidence on aspects of value where there is typically very little research evidence available. In this paper we have described an approach to addressing this challenge. The results presented are valuable for two reasons. First, a pragmatic approach to the generation of necessary evidence is presented. While this approach may seem rather obvious, the fact is MCDA and priority-setting processes that employ MCDA are often denigrated on the basis of the implied demands for information and the challenges that this poses. Second, this paper also provides a glimpse of the findings that were generated which may lead some readers to refer to the final report as a solid starting point for an application of MCDA involving any of the twelve areas of physiotherapy services studied.

\section{Competing interests}

This project was funded by the Canadian Physiotherapy Association. The views expressed in this paper are those of the authors and not necessarily those of the Canadian Physiotherapy Association.

\section{Authors' contributions}

FD and CM have made substantial contributions to the conception and design of the study, to the acquisition of data, and the analysis and interpretation of data. They have drafted the manuscript. TMD and CM have made substantial contributions to the conception and design of the study, to the acquisition of data, and to revising the manuscript critically for important intellectual content. MB has been involved in revising the manuscript critically for important intellectual content.

\section{Acknowledgements}

Thank you to Vicki Wong and Maggie Green, CPA, for their assistance in searching the literature and identifying the 12 key practice areas.

\section{Author details}

${ }^{1}$ Centre for Clinical Epidemiology and Evaluation, Vancouver Coastal Health Research Institute, School of Population and Public Health, University of
British Columbia, 7th Floor, 828 West 10th Avenue, Research Pavilion, Vancouver, BC V5Z 1M9, Canada. ${ }^{2}$ Canadian Physiotherapy Association, Ottawa, ON, Canada.

Received: 28 November 2012 Accepted: 2 May 2013

Published: 20 May 2013

\section{References}

1. Tsouraps A, Frew E: Evaluating 'success' in programme budgeting and marginal analysis: a literature review. J Health Serv Res Policy 2011, 16(3):177-183

2. Langer A: A framework for assessing Health Economic Evaluation (HEE) quality appraisal instruments. BMC Health Serv Res 2012, 12(1):253.

3. Williams I, Mclver S, Moore D, Bryan S: The use of economic evaluations in NHS decision-making: a review and empirical investigation. Health Technol Assess 2008, 12:7.

4. Hauck K, Smith PC, et al: The Economics of Priority Setting for Health Care. A Literature Review. Washington D.C: The World Bank; 2003.

5. Youngkong S, Teerawattananon Y, Tantivess S, Baltussen R: Multi-criteria decision analysis for setting priorities on HIV/AIDS interventions in Thailand. Health Res Pol Syst 2012, 10:6.http://www.health-policy-systems. com/content/10/1/6.

6. Thokala P: Mutiple criteria decision analysis for health technology assessment report by the decision support unit. Regent Court, 30 Regent Street, Sheffield, S1 4DA: School of Health and Related Research, University of Sheffield, UK Decision Support Unit, ScHARR, University of Sheffield; 2011

7. Baltussen R, Niessen L: Priority setting of health interventions: the need for multi-criteria decision analysis. Cost Effectiveness Resource Allocation 2006, 4:14. http://www.resource-allocation.com/content/4/1/14.

8. Peacock S, Mitton C, Bate A, McCoy B, Donaldson C: Overcoming barriers to priority setting using interdisciplinary methods. Health Policy 2009, 92:124-32.

9. Baltusen $\mathrm{R}$, Niessen L: Priority setting of health interventions: the need for multi-criteria decision analysis. Cost Effectiveness Resource Allocation 2006, 4:14

10. Devin N, Sussex J: Incorporating multiple criteria in HTA: methods and processes. London: Office of Health Economics; 2011.

11. Dionne F, Mitton C, Smith N, Donaldson C: Evaluation of the impact of program budgeting and marginal analysis in Vancouver Island Health Authority. J Health Serv Res Policy 2009, 14:234-242.

12. Mitton C, Dionne F, Damji R, Campbell D, Bryan S: Difficult decisions in times of constraint: Criteria based Resource Allocation in the Vancouver Coastal Health Authority. BMC Health Serv Res 2011, 11:169. http://www. biomedcentral.com/1472-6963/11/169.

13. Wilson E, Rees J, Fordham R: Developing a prioritisation framework in an English Primary Care trust. Cost effectiveness Resource Allocation 2006, 4:3.

14. Astley J, Wake-Dyster W: Evidence-based priority setting. Aust Health ReV 2001, 24(2):32-39.

15. Mitton C, Dionne F: Valuation of Physiotherapy Services in Canada. Final Report. Canadian Physiotherapy Association; 2012. in press.

16. Larsson L, Karlqvist L, Gard G: Effects of work ability and health promoting interventions for women with musculoskeletal symptoms: A 9-month prospective study. BMC Musculoskelet Disord 2008, 9:105. http://www. biomedcentral.com/1471-2474/9/105.

17. Freburger JK, Holmes GM, Carey TS: Physician referrals to physical therapy for the treatment of musculoskeletal conditions. Arch Phys Med Rehabil 2003, 84(12):1839-49.

18. Feldman DE, Bernatsky S, Lévesque JF, Van MT, Houde M, April KT: Access and perceived need for physical and occupational therapy in chronic arthritis. Disabil Rehabil 2010, 32(22):1827-32.

19. Critchley DJ, Ratcliffe J, Noonan S, Jones R, Hurley M: Effectiveness and cost-effectiveness of three types of physiotherapy used to reduce chronic low back pain disability: a pragmatic randomized trial with economic evaluation. Spine (Phila Pa 1976) 2007, 32(14):1474-81.

20. Torstensenm TA, Ljunggren AE, Meen HD, Odland E, Mowinckel P, af Geijerstam S: Efficiency and costs of medical exercise therapy, conventional physiotherapy, and self-exercise in patients with chronic low back pain: a pragmatic, randomized, single-blinded, controlled trial with 1-year follow-up. Spine (Phila Pa 1976) 1998, 23(23):2616-24.

21. Slade SC, Molloy E, Keating JL: People with non-specific chronic low back pain who have participated in exercise programs have preferences about exercise: a qualitative study. Aust J Physiother 2009, 55(2):115-121. 
22. Griffiths TL, Phillips CJ, Davies S, Burr ML, Campbell IA: Cost effectiveness of an outpatient multidisciplinary pulmonary rehabilitation programme. Thorax 2001, 56(10):779-84.

23. Evans RA, Goldstein RS: Pulmonary rehabilitation: An overview including new and innovative strategies. Pneumologica 2011, 50(1):47-61.

24. Larsen K, Hvass KE, Hansen TB, Thomsen PB, Soballe K: Effectiveness of accerlated perioperative care and rehabilitation intervention compared to current intervention after hip and knee arthroplasty. A before-after trial of 247 patients with a 3-month follow-up. BMC Musculoskelet Disord 2008, 9:59.

25. Dorr $L D$, Chao $L$ : The emotional state of the patient after total hip and knee arthroplasty. Clin Orthop Relat Res 2007, 463:7-12.

26. Grotle M, Garratt AM, Klokkerud M, Løchting I, Uhlig T, Hagen KB: What's in team rehabilitation care after arthroplasty for osteoarthritis? Results from a multicenter, longitudinal study assessing structure, process, and outcome. Phys Ther 2010, 90(1):121-31.

27. Edwards JD, Koehoorn M, Boyd LA, Levy AR: Is health-related quality of life improving after stroke? A comparison of health utilities indices among Canadians with stroke between 1996 and 2005. Stroke 2010, 41(5):996-1000. Epub 2010 Apr 1.

28. Fontan E: Long-term effectiveness of a home intervention to reduce functional problems: Results of a randomised, controlled trial. Cahiers de l'Année Gérontologique 2010, 2(3):188-190.

29. Madureira MM, Bonfá E, Takayama L, Pereira RM: A 12-month randomized controlled trial of balance training in elderly women with osteoporosis: improvement of quality of life. Maturitas 2010, 66(2):206-11. Epub 2010 Apr 14.

30. Long AR, Rouster-Stevens KA: The role of exercise therapy in the management of juvenile idiopathic arthritis. Curr Opin Rheumatol 2010, 22(2):213-7.

31. Martin L, Baker R, Harvey A: A systematic review of common physiotherapy interventions in school-aged children with cerebral palsy. Phys Occup Ther Pediatr 2010, 30(4):294-312.

32. van Doorn N: Exercise programs for children with cystic fibrosis: a systematic review of randomized controlled trials. Disabil Rehabil 2010, 32(1):41-9.

33. Ryburn B, Foreman P: Enabling independence: Restorative approaches to home care provision for frail older adults. Health Soc Care Community 2009, 17(3):225-234.

34. Lloyd JM, Martin R, Rajagopolan S, Zieneh N, Hartley R: An innovative and cost-effective way of managing ankle fractures prior to surgery-home therapy. Ann R Coll Surg Engl 2010, 92(7):615-618.

35. Langhorne P, Widen-Holmqvist L, Taylor G, Murray G, Askim T, Dennis M, Anderson C, Bautz-Holter E, Dey P, Indredavik B, Mayo N, Power M, Rodgers H, Ronning OM, Rudd A, Suwanwela N, Wolfe C: Early supported discharge after stroke. J Rehabil Med 2007, 39(2):103-108.

36. Clark AM, Haykowsky M, Kryworuchko J, MacClure T, Scott J, DesMeules M, Luo W, Liang Y, MCAlister FA: A meta-analysis of randomized control trials of home-based secondary prevention programs for coronary artery disease. Int J Cardiol 2006, 111(3):343-51. Epub 2005 Nov 28.

37. Gordon LG, Scuffham P, Battistutta D, Graves N, Tweeddale M, Newman B: A cost-effectiveness analysis of two rehabilitation support services for women with breast cancer. Breast Cancer Res Treat 2005, 94(2):123-33.

38. Sigurdsson E, Siggeirsdottir K, Jonsson H Jr, Gudnason V, Matthiasson T, Jonsson BY: Early discharge and home intervention reduces unit costs after total hip replacement: Results of a cost analysis in a randomized study. Int J Health Care Finance Econ 2008, 8(3):181-192.

39. Gitlin LN, Hauck WW, Winter L, Dennis MP, Schulz R: Effect of an In-Home Occupational and Physical Therapy Intervention on Reducing Mortality in Functionally Vulnerable Older People: Preliminary Findings. J Am Geriatr Soc 2006, 54:950-955.

40. Gillespie LD, Robertson MC, Gillespie WJ, Lamb SE, Gates S, Cumming RG, Rowe $\mathrm{BH}$ : Interventions for preventing falls in older people living in the community. Cochrane Database Syst Rev 2009, 2:Art.No:: CD007146. http:// www.ncbi.nlm.nih.gov/pubmed/19370674.

41. Malkoc M, Karadibak D, Yildirim Y: The effect of physiotherapy on ventilatory dependency and the length of stay in an intensive care unit. AMED 2009, 32(1):85-8.

42. Needham DM, Korupolu R, Zanni JM, Pradhan P, Colantuoni E, Palmer JB, Brower RG, Fan E: Early physical medicine and rehabilitation for patients with acute respiratory failure: a quality improvement project. Arch Phys Med Rehabil 2010, 91(4):536-42.
43. Morris PE, Goad A, Thompson C, Taylor K, Harry B, Passmore L, Ross A, Anderson L, Baker S, Sanchez M, Penley L, Howard A, Dixon L, Leach S, Small R, Hite RD, Haponik E: Early intensive care unit mobility therapy in the treatment of acute respiratory failure. Crit Care Med 2008, 36(8):2238-43.

44. O'Connor ED, Walsham J: Should we mobilise critically ill patients? A review. Crit Care Resusc 2009, 11(4):290-300.

45. Wild D: Pushing mobility can reduce costs, deaths in icu patients mortality falls by $25 \%$ after protocol introduced, $\$ 3$ million in annual savings projected. Clin Anesthesiol Issue 2011, 37:8.

46. Thomas AJ: Physiotherapy led early rehabilitation of the patient with critical illness. AMED 2011, 16(1):46-57.

47. Burtin C, Clerckx B, Robbeets C, Ferdinande P, Langer D, Troosters T, Hermans G, Decramer M, Gosselink R: Early exercise in critically ill patients enhances short-term functional recovery. Crit Care Med 2009, 37(9):2499-505.

48. Hanekom S, Louw Q, Coetzee A: Physiotherapy management of critically ill patients guided by an evidence based protocol is safe and effective: A preliminary study. In Conference: 23rd Annual Congress of the European Society of Intensive Care Medicine, Volume 36. ESICM Barcelona Spain: Conference Publication; 2010:\$324.

49. Heran BS, Chen JM, Ebrahim S, Moxham T, Oldridge N, Rees K, Thompson DR, Taylor RS: Exercise-based cardiac rehabilitation for coronary heart disease. Ann Phys Rehabil Med 2011, 54(3):132-43. Epub 2011 Mar 1.

50. Duarte FP, Haida A, Bousquet $M$, Richard L, Mauriège $P$, Guiraud T: Shortterm impact of a 4-week intensive cardiac rehabilitation program on quality of life and anxiety-depression. Eur J Cardiovasc Prev Rehabil 2010, 17(3):261-70.

51. Jolly K, Taylor RS, Lip GY, Stevens A: Home-based cardiac rehabilitation compared with centre-based rehabilitation and usual care: a systematic review and meta-analysis. Int J Cardiol 2006, 111(3):343-51. Epub 2005 Nov 28.

52. Lau PM, Chow DH, Pope MH: Early physiotherapy intervention in an Accident and Emergency Department reduces pain and improves satisfaction for patients with acute low back pain: a randomised trial. Aust J Physiother 2008, 54(4):243-9.

53. Bleakley CM, O'Connor SR, Tully MA, Rocke LG, Macauley DC, Bradbury I, Keegan S, McDonough SM: Effect of accelerated rehabilitation on function after ankle sprain: randomised controlled trial. BMJ 2010, 340: c1964. http://www.bmj.com/content/340/bmj.c1964.

54. Taylor NF, Norman E, Roddy L, Tang C, Pagram A, Hearn K: Primary contact physiotherapy in emergency departments can reduce length of stay for patients with peripheral musculoskeletal injuries compared with secondary contact physiotherapy: a prospective non-randomised controlled trial. Physiotherapy 2011, 97(2):107-14. Epub 2010 Dec 16.

55. Mahler MP, Zuger K, Kaspar K, Haefeli A, Jenni W, Leniger T, Beer JH: A cost analysis of the first year after stroke - early triage and inpatient rehabilitation may reduce long term costs. Swiss Med Wkly 2008, 138(31-32):459-465.

56. Saka O, Serra V, Samyshkin Y, Mcguire A, Wolfe C: Cost-effectiveness of stroke unit care followed by early supported discharge. Stroke 2009, 40:24-29.

57. Teasell RW, Foley NC, Salter KL, Jutai JW: A blueprint for transforming stroke rehabilitation care in Canada: the case for change. Arch Phys Med Rehabil 2008, 89(3):575-578.

58. Lindsay P, Bayley M, McDonald A, Graham ID, Warner G, Phillips S: Toward a more effective approach to stroke: canadian best practice recommendations for stroke care. CMAJ 2008, 178(11):1418-25.

59. Salter K, Jutai J, Hartley M, Foley N, Bhogal S, Bayona N, Teasell R: Impact of early vs delayed admission to rehabilitation on functional outcomes in persons with stroke. J Rehabil Med 2006, 38(2):113-7.

60. Schouten LMT, Hulscher MEJL, Akkermans R, van Everdingen JJE, Grol RPTM, Huijsman R: Factors that influence the stroke care team's effectiveness in reducing the length of hospital stay. Stroke 2008, 39:2515-2521.

61. Håland Haldorsen EM, Grasdal AL, Sture Skouen J, Erling Risa A, Kronholm K, Ursin $\mathrm{H}$ : Is there a right treatment for a particular patient group? Comparison of ordinary treatment, light multidisciplinary treatment, and extensive multidisciplinary treatment for long-term sick-listed employees with musculoskeletal pain. Pain January 2002, 95(1-2):49-63.

62. Belthur MV, Clegg J, Strange A: A physiotherapy specialist clinic in paediatric orthopaedics: is it effective? Postgrad Med J 2003, 79:699-702.

63. Taylor NF, Norman E, Roddy L, Tang C, Pagram A, Hearn K: Primary contact physiotherapy in emergency departments can reduce length of stay for 
patients with peripheral musculoskeletal injuries compared with secondary contact physiotherapy: a prospective non-randomised controlled trial. Physiotherapy 2011, 97(2):107-114.

64. Oldmeadow LB, Bedi HS, Burch HT, Smith JS, Leahy ES, Goldwasser M: Experienced physiotherapists as gatekeepers to hospital orthopaedic outpatient care. Med J Aust 2007, 186(12):625-8.

65. Skouen JS, Grasdal AL, Haldorsen EMH, Holger U: Relative costeffectiveness of extensive and light multidisciplinary treatment programs versus treatment as usual for patients with chronic low back pain on long-term sick leave: randomized controlled study. Spine (Phila Pa 1976) 2002, 27(9):901-909. discussion 909-10.

66. Patrick LE, Altmaier EM, Found EM: Long-term outcomes in multidisciplinary treatment of chronic low back pain: results of a 13-year follow-up. Spine (Phila Pa 1976) 2004, 29(8):850-855.

67. Storrø S, Moen J, Svebak S: Effects on sick-leave of a multidisciplinary rehabilitation programme for chronic low back, neck and shoulder pain: comparison with usual treatment. Trondheim, Norway: Clinic of Physical Medicine, The Norwegian University of Science and Technology.

68. Pinnington MA, Miller J, Stanley I: An evaluation of prompt access to physiotherapy in the management of low back pain in primary care. Fam Pract 2004, 21(4):372-380.

69. Gatchel RJ, Polatin PB, Noe C, Gardea M, Pulliam C, Thompson J: Treatment- and cost-effectiveness of early intervention for acute lowback pain patients: a one-year prospective study. J Occup Rehabil 2003, 13(1):1-9.

70. Jensen IB, Bergstrom G, Ljungquist T, Bodin L: A 3-year follow-up of a multidisciplinary rehabilitation programme for back and neck pain. Pain 2005, 115(3):273-283.

71. Hagen M, Grasdal A, Eriksen HR: Does early intervention with a light mobilization program reduce long-term sick leave for low back pain: a 3-year follow-up study. Spine (Phila Pa 1976) 2003, 28(20):2309-15. discussion 2316

72. Petterson SC, Mizner RL, Stevens JE, Raisis L, Bodenstab A, Newcomb W, Snyder-Mackler L: Improved function from progressive strengthening interventions after total knee arthroplasty: a randomized clinical trial with an imbedded prospective cohort. Arthritis Care Res 2009, 61(2):174-183

73. Sanchez LN, Castro-Sanchez AM, Mataran-Penarrocha GA, Arroyo-Morales M, del Mar S-JM, Moreno-Lorenzo C: Benefits of starting rehabilitation within 24 hours of primary total knee arthroplasty: randomized clinical trial. Clin Rehabil 2011, 25(6):557-566.

74. Munin MC, Rudy TE, Glynn NW, Crossett LS, Rubash HE: Early inpatient rehabilitation after elective hip and knee arthroplasty. JAMA 1998, 279(11):84757.

75. Lilikakis AK, Gillespie B, Villar RN: The benefit of modified rehabilitation and minimally invasive techniques in total hip replacement. Ann $R$ Coll Surg Engl 2008, 90(5):406-411.

76. Raphael M, Jaeger M, van Vlymen J: Easily adoptable total joint arthroplasty program allows discharge home in two days. Can J Anesthesia 2011, 58(10):902-910.

77. Husted H, Hansen HC, Holm G, Bach-Dal C, Rud K, Lande Andersen K, Kehlet $\mathrm{H}$ : What determines length of stay after total hip and knee arthroplasty? A nationwide study in Denmark. Arch Orthop Trauma Surg 2010, 130(2):263-268.

78. Iyengar KP, Nadkarni JB, Ivanovic N, Mahale A: Targeted early rehabilitation at home after total hip and knee joint replacement: Does it work? Disabil Rehabil 2007, 29(6):495-502.

79. Adami PE, Negro A, Lala N, Martelletti P: The role of physical activity in the prevention and treatment of chronic diseases. Clin Ter 2010, 161(6):537-41.

80. Park YH, Song M, Cho BL, Lim JY, Song W, Kim SH: The effects of an integrated health education and exercise program in communitydwelling older adults with hypertension: a randomized controlled trial. Patient Educ Couns 2011, 82(1):133-7.

81. Tumiati R, Mazzoni G, Crisafulli E, Serri B, Beneventi C, Lorenzi CM, Grazzi G, Prato F, Conconi F, Fabbri LM, Clini EM: Home-centred physical fitness programme in morbidly obese individuals: a randomized controlled trial. Clin Rehabil 2008, 22(10-11):940-50.

82. Ries AL, Make BJ, Reilly JJ: Pulmonary rehabilitation in emphysema. Proc Am Thorac Soc 2008, 5(4):524-9.
83. Ozdirenc M, Kocak G, Guntekin R: The acute effects of in-patient physiotherapy program on functional capacity in type II diabetes mellitus. Diabetes Res Clin Pract 2004, 64(3):167-72.

84. Bersoux S, Asbury KL, Cook CB, Verheijde JL, Larson MH, Aponte-Furlow RT, Flatten SS, Hooley SA, LaRosa CS, Seifert KM, Verona PM, Castro JC, Jameson KA: An outpatient-based clinical program for type 2 diabetes prevention. Endocr Pract 2010, 16(1):21-29.

85. Cameron ID, Murray GR, Gillespie LD, Robertson MC, Hill KD, Cumming RG, Kerse N: Interventions for preventing falls in older people in nursing care facilities and hospitals. Cochrane Database Syst Rev 2010(Issue 1):Art.No.: CD005465. http://onlinelibrary.wiley.com/doi/10.1002/14651858.CD005465. pub3/full.

86. Hektoen LF, Aas $E$, Luras $H$ : Cost-effectiveness in fall prevention for older women. Scand J Public Health 2009, 37(6):584-589.

87. Thomas S, Maclntosh S, Halbert J: Does the 'Otago exercise programme' reduce mortality and falls in older adults? a systematic review and metaanalysis. Age Ageing 2010, 39(6):687.

88. Sherrington C, Whitney JC, Lord SR, Herbert RD, Cumming RG, Close JCT: Effective exercise for the prevention of falls: a systematic review and meta-analysis. J Am Geriatr Soc 2008, 56(12):2234-2243.

89. Hauer K, Rost B, Rutschle K, Opitz H, Specht N, Bartsch P, Oster P, Schlierf G Exercise training for rehabilitation and secondary prevention of falls in geriatric patients with a history if injurious falls. J Am Geriatr Soc 2001, 49(1):10-20.

90. Bialoszewski D, Sllupik A, Lewcsuk E, Gotlib J, Mosiolek A, Mierzwinska A: Incidence of falls and their effort on mobility of individuals over 65 years of age relative to their place of residence. Ortop Traumatol Rehabil 2008, 10(5):441-8.

91. Garvey C, Fromer L, Saver DF, Yawn BP: Pulmonary rehabilitation: an underutilized resource in primary COPD care. Phys Sportsmed 2010, 38(4):54-60

92. Waterhouse JC, Walters SJ, Oluboyede $\mathrm{Y}$, Lawson RA: A randomised $2 \times 2$ trial of community versus hospital pulmonary rehabilitation for chronic obstructive pulmonary disease followed by telephone or conventional follow-up. Health Technol Assess 2010, 14(6):1-164.

93. Rubí M, Renom F, Ramis F, Medinas M, Centeno MJ, Górriz M, Crespí E, Martín B, Soriano JB: Effectiveness of pulmonary rehabilitation in reducing health resources use in chronic obstructive pulmonary disease. Arch Phys Med Rehabil 2010, 91(3):364-8.

94. Rasekaba TM, Williams E, Hsu-Hage B: Can a chronic disease management pulmonary rehabilitation program for COPD reduce acute rural hospital utilization? Chron Respir Dis 2009, 6(3):157-63.

95. Johnston K, Grimmer-Somers K: Pulmonary rehabilitation: overwhelming evidence but lost in translation? Physiother Can 2010, 62(4):368-73. Epub 2010 Oct 18.

96. Griffiths TL, Phillips CJ, Davies S, Burr ML, Campbell IA: Cost effectiveness of an outpatient multidisciplinary pulmonary rehabilitation programme. AMED 2001, 56(10):779-84.

97. Hoogendoorn M, Van Wetering CR, Schols AM, Rutten-van Molken MPMH: Is INTERdisciplinary COMmunity-based COPD management (INTERCOM) cost-effective? Eur Respir J 2010, 35(1):79-87.

98. Golmohammadi K, Jacobs P, Sin DD: Economic evaluation of a community-based pulmonary rehabilitation program for chronic obstructive pulmonary disease. Lung 2004, 182(3):187-196.

99. Ninot G, Moullec G, Picot MC, Jaussent A, Hayot M, Desplan M, Brun JF, Mercier J, Prefaut C: Cost-saving effect of supervised exercise associated to COPD self-management education program. Respir Med 2011, 105(3):377-85. Epub 2010 Oct 29.

100. Brouselle A, Lessard C: Economic evaluation to inform health care decision-making: Promise, pitfalls and a proposal for an alternative path. Soc Sci Med 2011, 72:832-839.

101. Maiwenn JA, Feenstra T, Brouwer WBF: Decisionmakers' views on healthcare objectives and budget constraints: results from a pilot study. Health Policy 2004, 70(1):33-34.

doi:10.1186/1478-7547-11-11

Cite this article as: Dionne et al:: The challenge of obtaining information necessary for multi-criteria decision analysis implementation: the case of physiotherapy services in Canada. Cost Effectiveness and Resource Allocation 2013 11:11. 